OPEN ACCESS

Edited by:

Theoharis Constantin

Theoharides,

Tufts University School of Medicine,

United States

Reviewed by:

Elsa Fabbretti,

University of Trieste, Italy

Pio Conti,

Università degli Studi G. d'Annunzio

Chieti e Pescara, Italy

${ }^{*}$ Correspondence:

Hanna Siiskonen

hanna.siiskonen@kuh.fi

Ilkka Harvima

ilkka.harvima@kuh.fi

Specialty section:

This article was submitted to

Cellular Neuropathology,

a section of the journal

Frontiers in Cellular Neuroscience

Received: 15 November 2018

Accepted: 03 September 2019

Published: 18 September 2019

Citation:

Siiskonen H and Harvima I (2019)

Mast Cells and Sensory Nerves

Contribute to Neurogenic

Inflammation and Pruritus in Chronic

Skin Inflammation.

Front. Cell. Neurosci. 13:422.

doi: 10.3389/fncel.2019.00422

\section{Mast Cells and Sensory Nerves Contribute to Neurogenic Inflammation and Pruritus in Chronic Skin Inflammation}

\author{
Hanna Siiskonen* and Ilkka Harvima* \\ Department of Dermatology, Kuopio University Hospital and University of Eastern Finland, Kuopio, Finland
}

The intimate interaction between mast cells and sensory nerves can be illustrated by the wheal and surrounding flare in an urticarial reaction in human skin. This reaction is typically associated with an intense itch at the reaction site. Upon activation, cutaneous mast cells release powerful mediators, such as histamine, tryptase, cytokines, and growth factors that can directly stimulate corresponding receptors on itch-mediating sensory nerves. These include, e.g., H1- and H4-receptors, proteaseactivated receptor-2, IL-31 receptor, and the high-affinity receptor of nerve growth factor (TrkA). On the other hand, sensory nerves can release neuropeptides, including substance $P$ and vasoactive intestinal peptide, that are able to stimulate mast cells to release mediators leading to potentiation of the reciprocal interaction, inflammation, and itch. Even though mast cells are well recognized for their role in allergic skin whealing and urticaria, increasing evidence supports the reciprocal function between mast cells and sensory nerves in neurogenic inflammation in chronic skin diseases, such as psoriasis and atopic dermatitis, which are often characterized by distressing itch, and exacerbated by psychological stress. Increased morphological contacts between mast cells and sensory nerves in the lesional skin in psoriasis and atopic dermatitis as well as experimental models in mice and rats support the essential role for mast cellsensory nerve communication in consequent pruritus. Therefore, we summarize here the present literature pointing to a close association between mast cells and sensory nerves in pruritic skin diseases as well as review the essential supporting findings on pruritic models in mice and rats.

Keywords: mast cell, sensory neuron, itch, skin, pruritus

\section{INTRODUCTION}

Itching is a very unpleasant sensation that may provoke scratching or the desire to scratch (Savin, 1998). Chronic itch has clinically been classified into 3 groups according to skin changes: (1) pruritus on primary diseased, inflamed skin; (2) pruritus on primary non-diseased, noninflamed skin; and (3) pruritus with chronic secondary scratch lesions. Pruritus has also been 
categorized based on underlying diseases as following: (1) dermatological diseases; (2) systemic diseases including diseases of pregnancy and drug-induced pruritus; (3) neurological diseases; (4) psychiatric/psychosomatic diseases; (5) mixed; and (6) others (Ständer et al., 2007b). Based on its duration, itch can be divided into acute (less than 6 weeks) and chronic (more than 6 weeks) (Azimi et al., 2016).

In the skin, the perception of itch originates from the combined action of nervous, cutaneous and inflammatory cells and substances released by them in the microenvironment. In humans, the nerves responsible for the perception of itch also react to stimuli of pain. There are two types of pruriceptors, specialized nerve fibers sensing itch: fastly conducting A-fibers and non-myelinated, slowly conducting C-fibers, which can be further subdivided based on their responsiveness to different chemical or physical stimuli [reviewed in detail in (LaMotte et al., 2014)].

The itch-specific peripheral sensory neurons may be a subgroup of nociceptive neurons. Subsets of mechanoinsensitive nociceptive $\mathrm{C}$-fibers can respond to histamine resulting in the release neuropeptides, including substance $\mathrm{P}$ and calcitonin gene -related peptide (CGRP). Instead, the mechano/heat-sensitive nociceptors are not reactive to histamine, but show a response to a cowhage plant protease, leading to stinging itch, which is possibly mediated via protease-activated receptor-2 or -4 (PAR-2 or -4). This type of stinging itch resembles that in skin inflammatory diseases. Nevertheless, cutaneous nerves contain a range of different receptors and ion channels. Therefore, different combinations of receptors may produce a certain type of itch and/or pain sensation. In the spinal dorsal horn, gastrin-releasing peptideexpressing neurons participate in the transmission of itch (Albisetti et al., 2019). The sensing system is further complexed by excitatory interneurons, spinothalamic tract neurons and the central nervous system where these sensations are recognized (Baraniuk, 2012; LaMotte et al., 2014; Talagas et al., 2018). Furthermore, it is noteworthy that chronic inflammation in skin causes additional changes to the neural and proinflammatory cell network.

Free nerve endings in the epidermis are important for sensing itch. It has been proposed that there is a reciprocal synapticlike interaction between nerves and keratinocytes (Talagas et al., 2018). One possible mediator in this interaction is ß-endorphin, as keratinocytes expressing this mediator have been found around unmyelinated fibers that can be activated via $\mu$-opioid receptor (Bigliardi-Qi et al., 2004). In fact, the whole complex of nerve fibers and the epidermal cells have been proposed to form the "itch receptor" (Greaves, 2010). The skin cells themselves express a wide array of mediators and their receptors involved in the perception of itch (Greaves, 2010). In addition to nerve fibers and epidermal cells, the cells of the immune system constitute yet another part in pruritus. In regard to cellular events in itching skin, mast cells are important players that are involved in neurogenic inflammation and its associated itch. In this review, the fundamental role of mast cells and sensory nerves in itch is discussed.

\section{ITCH-RELATED PROPERTIES OF MAST CELLS}

Mast cells are important effector cells in allergic reactions and immunity [reviewed in Conti et al. (2017)], but they also contribute to carcinogenesis (Biswas et al., 2014; Hu et al., 2018; Saadalla et al., 2018). Mast cells are abundant in bodyenvironment interfaces in the skin and the gastrointestinal tract (Gurish and Austen, 2001) as well as present in the meninges of the central nervous system (Bo et al., 1992; Theoharides et al., 2005), and in the lung (Bradding et al., 2006). In the skin, mast cell numbers are highest in the upper dermis and their numbers are not affected by age or sex (Weber et al., 2003), but increase in response to various environmental stimuli as shown after ultraviolet radiation in human skin (Grimbaldeston et al., 2003; Kim et al., 2009), and after exposure to topical sensitizing agents in mice (Kitagaki et al., 1995; Tomimori et al., 2002). It is thus obvious that mast cells constitute an inherent component of itch.

Mast cells are fully loaded with preformed mediators or they produce newly-synthesized mediators, including proteases, histamine, lipid-derived mediators, cytokines, and chemokines which they release upon activation through a variety of mechanisms leading to degranulation, piecemeal degranulation, and/or mediator secretion without degranulation [reviewed in da Silva et al. (2014) and in Gupta and Harvima (2018)]. In type I hypersensitivity, mast cell degranulation is a fundamental event and involves crosslinking of an antigen with two $\operatorname{IgE}$ molecules bound to FceRI receptors (Owen et al., 2013). Mast cell activation has been studied especially in the context of urticaria. It is known that several factors such as infections, stress, certain foods, pseudoallergens, hormones, neuropeptides, and Th2 inflammation may prime mast cells [reviewed in Church et al. (2018)]. Also autoimmune mechanisms may lead to mast cell activation. In these cases, IgE recognizes dermisderived autoantigens, of which more than 200 are present in chronic spontaneous urticaria (Schmetzer et al., 2018). Another mechanism is the presence of IgG or IgM class antibodies against IgE (Gruber et al., 1988) or against its FceRI receptor (Hide et al., 1993). These autoantibodies may also target the eosinophils, which release mast-cell activating factors (Puccetti et al., 2005).

\section{ITCH-RELATED FACTORS RELEASED BY MAST CELLS}

Mast cells release the contents of their secretory granules to their surroundings upon degranulation. Many of these granule mediators or mediators synthesized de novo (Harvima et al., 2014) participate in the development of itch.

\section{Histamine and Its $\mathrm{H} 1$ and H4 Receptors}

Histamine is the most important pruritogenic mediator of mast cells. Histamine has four receptors, namely $\mathrm{H} 1-\mathrm{H} 4$, of which $\mathrm{H} 1$ and $\mathrm{H} 4$ are important in pruritus. The function of these receptors in itch has been mainly studied in mouse models, and it has been shown that skin sensory neurons express $\mathrm{H} 1$, 
H3 and H4 (Rossbach et al., 2011). In mouse models, H1antagonists have been effective in decreasing itch, which has been known already for decades (Sugimoto et al., 1998), although H4antagonists (Dunford et al., 2007; Yamaura et al., 2009) have proved to be more potent. Histamine acts also on Transient receptor potential vanilloid receptor-1 (TRPV-1) in sensory neurons (Shim et al., 2007). In keratinocytes, also TRPV-4 is a histaminergic pruriceptor (Chen et al., 2016).

\section{Tryptase and PAR-2}

Tryptase, one of the main proteinases secreted by mast cells, can induce pruritus in mice and its effects are inhibited by PAR-2 antibody or PAR-2 antagonist, showing that PAR-2 is involved in tryptase-induced pruritus (Ui et al., 2006). Involvement of tryptase and PAR-2 in itch has also been reported in a mouse model of atopic dermatitis (Zhu et al., 2015). In line with these data, non-lesional and lesional skin biopsies from patients with atopic dermatitis show PAR-2 in sensory nerves with closely located mast cells (Steinhoff et al., 2003).

\section{IL-31 and Its Receptor IL-31RA}

Interleukin-31 (IL-31) is important in the pruritus of atopic dermatitis (Sonkoly et al., 2006) and it also participates in the itch of cutaneous lymphoma (Nattkemper et al., 2016). IL-31 has been shown to increase the growth and sprouting of cutaneous sensory nerves (Feld et al., 2016), which express its receptor, IL-31RA (Cevikbas et al., 2014).

Interleukin-31 has been demonstrated to induce mild itch that appears slowly starting at 143 min after skin prick test, which is associated with a long-lasting erythema. By comparison, histamine induces immediate itch that starts within 5 min after skin prick test (Hawro et al., 2014). Human mast cells (Niyonsaba et al., 2010; Petra et al., 2018) and T-cells (Dillon et al., 2004) are sources of IL-31 in skin, thus participating in the development of itch. Moreover, mast cell-derived histamine in addition to IL31 increase the secretion of brain-derived natriuretic peptide, which in turn affects dendritic cells and keratinocytes to produce cytokines and other mediators, leading to inflammation, and increased itch signaling (Meng et al., 2018).

\section{Leukotrienes and Prostaglandins}

Leukotrienes and prostaglandins are also involved in itch, but by different mechanism. When administered intradermally, leukotriene B4 induces itch while prostaglandin E2 does not (Andoh and Kuraishi, 1998). Leukotriene B4 is released from keratinocytes in response to PAR-2 receptor activation (Zhu et al., 2009) and it is involved in the itch-causing cascades of substance P (Andoh et al., 2001) and IL-31 (Andoh et al., 2017a). PAR-2 activation and leukotriene B4 release participate also in dermatophyte-induced itch (Andoh et al., 2014). In addition to producing leukotriene B4 by themselves (Satpathy et al., 2015), human, and murine mast cells also express leukotriene B4 receptors BLT1 and BLT2 (Lundeen et al., 2006). On the contrary, prostaglandin D2, also produced by mast cells themselves (Murakami et al., 1995), decreases histamine release from mast cells and inhibits scratching in a mouse model (Hashimoto et al., 2005). Thus, it seems that mast cells release many mediators that also control their own function.

\section{Neuropeptides and Mast Cell Activation}

There are several neuropeptides released by the sensory neurons in the skin, which then activate mast cells. Mast cells degranulate in response to nerve growth factor (NGF) and this signaling acts through TrkA tyrosine receptor (Horigome et al., 1993). Interestingly, mast cells can secrete NGF also by themselves suggesting an autocrine or paracrine mechanism (Nilsson et al., 1997).

The potency of substance $P$ in degranulating mast cells and causing itchy wheals was found already decades ago (Hägermark et al., 1978). The effects of substance $\mathrm{P}$ on mast cells are mediated either through neurokinin-1 receptor (NK-1R) or Mas-related G protein coupled receptor-X2 (MRGPRX2) (Kulka et al., 2008; Subramanian et al., 2016). In the initial phases of topical therapy with calcineurin inhibitors pimecrolimus and tacrolimus, pruritus and burning is often present. These compounds have been shown to release substance P and CGRP from primary afferent nerve endings in murine skin, leading to mast cell degranulation and thus release of pruritogenic histamine, and tryptase (Ständer et al., 2007a). Mast cells degranulate rapidly in response to substance $\mathrm{P}$ resulting in wheal reaction in the skin (Huttunen et al., 1996; Yamaoka and Kawana, 2007). The ability of substance $P$ to induce histamine release seems to appear only at high concentrations (Weidner et al., 2000). In line with this, substance P decreases mast cell recruitment and degranulation when used as a topical treatment in a murine model of atopic dermatitis (Choi et al., 2018), pointing to a concentration-dependent dual role of substance $\mathrm{P}$.

Interestingly, stimulation of human mast cells with substance $\mathrm{P}$ and an IL-1 family member, IL-33, increase the secretion of proinflammatory TNF and IL-1 $\beta$ and these responses are inhibited by a natural flavonoid, methoxyluteolin (Taracanova et al., 2017, 2018). A pure luteolin with Ashwagandha has been proposed as a relief to patients suffering from stress and inflammation-associated diseases (Theoharides and Kavalioti, 2018). This release of cytokines is potentially inhibited also by IL-37, another IL-1 family cytokine [reviewed in Caraffa et al. (2018), Tettamanti et al. (2018), Gallenga et al. (2019)]. The effect of substance $\mathrm{P}$ to release proinflammatory cytokines from mast cells points to a mechanism how mast cells participate in the neurogenic inflammation in psoriasis and atopic dermatitis as discussed below in more detail. Recently, Nakamura et al. (2019) reported increased levels of IL-33 in the stratum corneum of patients with atopic dermatitis. All these data emphasize the role of these cytokines in the context of neuroinflammation and itch, in which mast cells obviously participate.

Vasoactive intestinal peptide (VIP) is another potent neuropeptide to degranulate mast cells (Fjellner and Hägermark, 1981; Huttunen et al., 1996), a reaction mediated through VPAC2, and/or MRGPRX2 receptors on mast cells (Kulka et al., 2008; Subramanian et al., 2016). In addition, substance P and VIP have been found to stimulate human mast cells in vitro 
conditions to release cytokines and chemokines, including TNF$\alpha$, GM-CSF, IL-3, CCL2, CCL5, CXCL8, CXCL9, and CXCL10 (Kulka et al., 2008).

\section{MAST CELLS, SKIN DISEASES, AND ITCH}

In a retrospective study conducted by Sommer et al. (2007), dermatological disease was the probable cause of the itch in $41,8 \%$ of patients, while almost a similar number of cases $(44,8$ $\%)$ showed no apparent origin of the symptoms. The role of mast cells in the development of itch has been studied mostly in psoriasis, atopic dermatitis and urticaria. It is likely that the increased contacts between nerve fibers and mast cells often seen in these dermatoses constitute the morphological basis for itch chronicization during chronic skin inflammation. The current understanding of the role of mast cells and sensory nerves in itch in these and selected other pruritic dermatoses is discussed here next.

\section{Mast Cells, Sensory Nerves, and Itch in Psoriasis}

Psoriasis, a common chronic inflammatory and scaly skin disease, is characterized by pruritus that affects $60-90 \%$ of the patients and can appear in different forms, such as stinging, pinching, tickling, crawling, burning or pain sensations (Szepietowski and Reich, 2016). On the other hand, psychosocial stress can exacerbate psoriasis in $40-80 \%$ of the patients (Basavaraj et al., 2011). Thus, pruritus and stress may be reciprocally interconnected factors in psoriasis.

Emotional stress is associated with the activation of a variety of neuro-immune-endocrine systems. For example, the hypothalamic-pituitary-adrenal (HPA) axis is activated and stress hormones are released, including corticotropingreleasing hormone (CRH), adrenocorticotropic hormone, and glucocorticoids. Interestingly, human skin has its own functional peripheral equivalent of the HPA axis. Furthermore, numerous other factors are activated in stress, such as $\alpha-\mathrm{MSH}$, neuropeptides, neurotrophins and the sympathetic nervous system (Arck et al., 2006).

Several studies have previously shown that sensory nerve fibers and neuropeptides, including substance $\mathrm{P}$, neurokinin A and VIP, are increased in the psoriatic lesion (Naukkarinen et al., 1989; Eedy et al., 1991; Amatya et al., 2011). Furthermore, the morphologic contacts between neurofilament ${ }^{+}$nerves and tryptase $^{+}$mast cells are more frequent in psoriatic lesions than in non-lesional psoriatic skin or normal skin (Naukkarinen et al., 1991, 1993). Even the morphologic contacts between substance $\mathrm{P}^{+}$and $\mathrm{CGRP}^{+}$fibers and tryptase ${ }^{+}$mast cells, but not the contacts between $\mathrm{VIP}^{+}$fibers and tryptase ${ }^{+}$mast cells, have been found to be increased in the psoriatic lesion. Therefore, there is a morphologic basis for mast cell-neural interaction as well as neurogenic inflammation in psoriasis.

The increase in mast cell numbers, especially the $\mathrm{MC}_{\mathrm{TC}}$-type (tryptase $^{+}$and chymase ${ }^{+}$) of mast cell, in the psoriatic lesion has been known for decades. However, in contrast to the resistant tryptase, chymase is sensitive to the action of serum protease inhibitors, which may explain the finding that the enzyme activity of chymase is decreased in the psoriatic lesion (Harvima et al., 2008). The net outcome of the partial inactivation of chymase may be an uncontrolled and enhanced substance P-mediated neurogenic inflammation, as chymase degrades substance $\mathrm{P}$ and VIP, but tryptase degrades VIP and CGRP (Caughey et al., 1988; Franconi et al., 1989; Walls et al., 1992). Tryptase has the capability to cleave and activate the PAR-2 receptor. Therefore, the serine proteinase may not only activate the receptor on nerves and numerous proinflammatory cells but it may activate PAR-2 on mast cells themselves in a para- or autocrine fashion, as the percentage of tryptase ${ }^{+}$mast cells containing PAR-2 immunoreactivity is increased in the psoriatic lesion (Carvalho et al., 2010). Furthermore, the activation of PAR-2 sensitizes TRPV-1 leading to increased substance $P$ and CGRP release (Amadesi et al., 2004) and TRPV-1 is expressed in substance $\mathrm{P}^{+}$ fibers as well as in mast cells in human skin (Ständer et al., 2004).

In addition to neuropeptides, the emotional stress in psoriasis may transmit its signals to the skin through $\mathrm{CRH}$ and $\mathrm{CRH}-$ $\mathrm{R} 1$ receptor on mast cells as suggested previously (Harvima and Nilsson, 2012). This hypothesis is supported by a report that the immunostaining of CRH is increased in the epidermis, sweat glands, and hair follicles in the psoriatic lesion (Kim et al., 2007). In addition, we have analyzed the expression of CRHR1 immunoreactivity in mast cells in psoriasis and found that the percentage of tryptase ${ }^{+}$mast cells expressing CRH-R1 is higher in the lesional than non-lesional skin of 8 psoriatic patients (Haimakainen $\mathrm{S}$ et al., unpublished results).

There are several studies that have investigated molecular differences in skin between pruritic and non-pruritic-type of psoriasis. For example, the pruritic-type of psoriasis is characterized by increased levels of substance $P$ and nerve fibers; decreased levels substance P-degrading neutral endopeptidase; increased levels of NGF and/or its receptor TrkA (Nakamura et al., 2003; Chang et al., 2007; Amatya et al., 2011), decreased expression of semaphorin-3A (an axon-guidance molecule) (Taneda et al., 2011; Kou et al., 2012), and increased numbers of total and degranulated mast cells (Nakamura et al., 2003).

\section{Mast Cells, Sensory Nerves, and Itch in Atopic Dermatitis}

Atopic dermatitis (AD) is a well-known chronic eczematous skin disease characterized by distressing pruritus that can be exacerbated by inflammatory mediators, sensory nerves, skin dryness, heat, sweat, and emotional stress (Suarez et al., 2012; Murota and Katayama, 2017).

Like in the case of psoriasis, mast cells and sensory nerves have been suggested to play a role in neurogenic inflammation and itch in AD. Regarding mast cells, there are similarities between these diseases. In the lesional atopic dermatitis skin, the number of tryptase ${ }^{+}$mast cells is increased slightly, but the activity of chymase is decreased (Järvikallio et al., 1997; Ilves and Harvima, 2015). Like in psoriasis, the possible explanation for the partial inactivation of chymase in $\mathrm{AD}$ is the presence of chymase inhibitors in mast cells (Saarinen et al., 2001). The 
reduced chymase activity means that the enzyme cannot degrade and control efficiently a variety of proinflammatory peptides and proteins, including IL-6, IL-13, TNF- $\alpha$, IL-4, IL-5, substance P, and VIP (Franconi et al., 1989; Tunon de Lara et al., 1994; Zhao et al., 2005).

This is relevant for the inflammation, as the percentage of mast cells expressing TNF- $\alpha$, IL-4, IL-6, and CD30 ligand is increased in the lesional AD skin (Horsmanheimo et al., 1994; Ackermann and Harvima, 1998; Fischer et al., 2006; Ilves and Harvima, 2015). In addition, the severity of itching and tryptase ${ }^{+}$and IL- $6^{+}$mast cells correlate inversely with the (pro)filaggrin immunostaining in the epidermis of AD skin (Ilves et al., 2015).

Like in the case of psoriasis, there is an increased sensory nerve density in the epidermis and dermis in $\mathrm{AD}$ lesions, which suggests an enhanced neurogenic inflammation (Tobin et al., 1992; Urashima and Mihara, 1998; Järvikallio et al., 2003; Tominaga et al., 2009; Kubanov et al., 2015). Previously, it has been demonstrated that there is an increased expression of NGF and amphiregulin in the epidermis, but decreased expression of nerve repulsion factors, semaphorin-3A and anosmin-1, in AD lesions, which can explain the increased nerve density in $\mathrm{AD}$ (Tominaga et al., 2009; Tominaga and Takamori, 2014; Kubanov et al., 2015). In addition, another explanation for the increased nerve density is the finding that the expression of NGF is elevated in mast cells in AD lesions, and mast cells can express the receptor of NGF, i.e., TrkA (Nilsson et al., 1997; Xiang and Nilsson, 2000; Groneberg et al., 2005). There are also other regulatory mechanisms between NGF and tryptase, as NGF treatment of mast cells in vitro can increase the expression of TrkA as well as the contents of tryptase and histamine (Groneberg et al., 2005), and tryptase can generate mature NGF from pro-NGF (Spinnler et al., 2011). These molecular interactions can explain, at least in part, the finding that the morphologic contacts between tryptase ${ }^{+}$ mast cells and neurofilament ${ }^{+}$fibers are increased in AD lesions (Järvikallio et al., 2003).

Acute psychologic stress can result in marked changes in nerves, neuropeptides and mast cells. For example, the exposure of AD patients to acute Trier social stress test (TSST) associated with decreased $\mathrm{NGF}^{+}$and PGP9.5 $5^{+}$fibers and decreased contacts between PGP9. $5^{+}$fibers and tryptase ${ }^{+}$mast cells in AD lesions. However, in the non-lesional AD skin, these parameters increased, rather than decreased. Moreover, a positive correlation was observed between itch and mast cell-nerve fiber contacts in the non-lesional AD skin after TSST or lesional AD skin before TSST (Peters et al., 2014).

The classic histaminergic itch is mediated via H1-receptors on cutaneous sensory nerves, though H4-receptors on nerves can also be involved in pruritus (Ohsawa and Hirasawa, 2014). However, antihistamines usually are not effective in relieving distressing pruritus in chronic skin inflammation. The reason is the non-histaminergic itch that can be mediated through other distinct pathways. The PAR-2 activation on sensory fibers is one of them, as PAR-2 ${ }^{+}$fibers are increased in AD lesions. Therefore, tryptase released from mast cells can activate PAR2 on nerve fibers with subsequent release of substance $\mathrm{P}$ and CGRP and potentiation of neurogenic inflammation (Steinhoff et al., 2003; Kempkes et al., 2014). Interestingly, lichenified lesions of atopic dermatitis showed no staining for substance $\mathrm{P}$ or VIP nor degranulated mast cells, suggesting that other factors may contribute to pruritus in chronic, lichenified lesions (Urashima and Mihara, 1998).

Interleukin-31 can represent another pathway for nonhistaminergic itch in AD. This cytokine is derived from Th2 cells and mast cells. In the psoriatic and $\mathrm{AD}$ lesions, mast cells show increased levels of IL-31 immunoreactivity compared to normal skin (Niyonsaba et al., 2010). The expressions of the mRNA of IL-31 and its receptor IL-31RA are increased in $\mathrm{AD}$, but not psoriatic, lesions. Furthermore, the receptor is located in small-diameter neurons of human dorsal root ganglia (Sonkoly et al., 2006; Cevikbas et al., 2014).

Interleukin-31 may not only induce slowly developing itch (Hawro et al., 2014), but it may also increase the elongation, branching and density of nerves in AD lesions (Feld et al., 2016).

\section{Mast Cells, Sensory Nerves, and Itch in Urticaria}

Urticaria is a fundamentally mast cell-driven disease, in which pruritus is a key symptom in addition to wheals and/or angioedema (Zuberbier et al., 2018). In urticaria, it is the degranulation of mast cells and release of their mediators that cause the symptoms by activating sensory nerves and causing vasodilatation and plasma extravasation (Zuberbier et al., 2018). Although the details of mast cell activation in urticaria are not known yet, mast cells may be activated in urticaria by allergens/autoallergens or IgG antibodies against IgE or its receptor. In patients with chronic urticaria, more than 200 autoantigens reacting with IgE have been detected and of these, IL-24 is a common and functional autoantigen recognized by IgE antibodies (Schmetzer et al., 2018).

Interestingly, also a plethora of other agents are known to prime mast cells for further activation [reviewed in Church et al. (2018)]. Recently, a mouse model showed that Mrgprb2, the ortholog of the human MRGPRX2, and might be a mast cellspecific key receptor in pseudoallergic reactions (McNeil et al., 2015). This receptor is upregulated in the skin of patients with severe chronic urticaria (Fujisawa et al., 2014).

\section{Mast Cells, Sensory Nerves, and Itch in Selected Other Dermatoses}

Prurigo nodularis (PN) is a typical example of an itchy dermatosis. The close contact of mast cells and nerve fibers in PN lesions was reported already 20 years ago by Liang et al. (1998). They also noticed that there are increased mast cell numbers in the lesions. There are several other pruritic skin diseases, in which the changes in mast cell numbers have been investigated and they definitely participate in the pathogenesis, although the exact details of their role in pruritus in these dermatoses is not clear yet. Mast cell numbers are increased already in the perilesional skin in patients with hidradenitis suppurativa (HS) and the numbers are further elevated in early and chronic lesions (van der Zee et al., 2012). In line with this finding, about $60 \%$ of patients with HS report moderate or severe pruritus (Matusiak et al., 2018). Similarly, more than one third of patients 
with basal cell carcinoma or squamous cell carcinoma report to have pruritus (Mills et al., 2012; Yosipovitch et al., 2014) and elevated mast cell numbers in both tumors have been reported (Diaconu et al., 2007; Haimakainen et al., 2017). The connection between mast cell numbers and itch is not so clear in melanoma, in which less patients report itch (Yosipovitch et al., 2014) and both increased (Toth-Jakatics et al., 2000; Ribatti et al., 2003a,b), and decreased (Biswas et al., 2014; Siiskonen et al., 2015; Rajabi et al., 2017) mast cell numbers have been reported. However, since the exact functions of mast cells in skin cancers are not known at the moment, also their role in itch remains unclear.

\section{Animal Models in Research on Mast Cells and Itch}

The growing research performed in experimental animals has revealed that the molecular mechanisms of pruritus as well as the ligands and receptors involved in itch induction are more complex than thought, and it is beyond the scope if this review to describe them all.

Animal models to study pruritus have been mainly developed for AD. Subcutaneous capsaicin injections to neonatal rats causes long-lasting, pruritic skin changes with histopathological findings resembling $\mathrm{AD}$, including increased mast cell number (Back et al., 2012). The Kyoto Fancy Rat Stock 4 is another rat model of $\mathrm{AD}$ showing spontaneous itchy dermatitis with increased transepidermal water loss and mast cell numbers (Kuramoto et al., 2015). The bile duct ligation rat model of liver disease has provided a good insight to neuroinflammation and itch. In these rats, PAR-2 receptors are activated and this potentiates the TRPV-1 channels (Belghiti et al., 2013). As discussed above, mast cell tryptase may activate PAR-2, pointing to a role for mast cells also in hepatic pruritus. Elevated tryptase and PAR2 levels are also found in a mouse model with ovalbumininduced AD-like dermatitis (Zhu et al., 2015). Mast cells and sensory nerves can be found in apparent morphologic contact in the skin. For example, in a mouse model of hapten-induced $\mathrm{AD}$, mast cells in the lesional skin express high levels of cell adhesion molecule-1 (CADM-1), a molecule that was found to enhance adhesion and communication between sensory nerves and mast cells in vitro (Hagiyama et al., 2013). Human mast cells have also been found to express CADM-1 that probably interacts with nectin-3 on nerves (Furuno et al., 2012; Moiseeva et al., 2013).

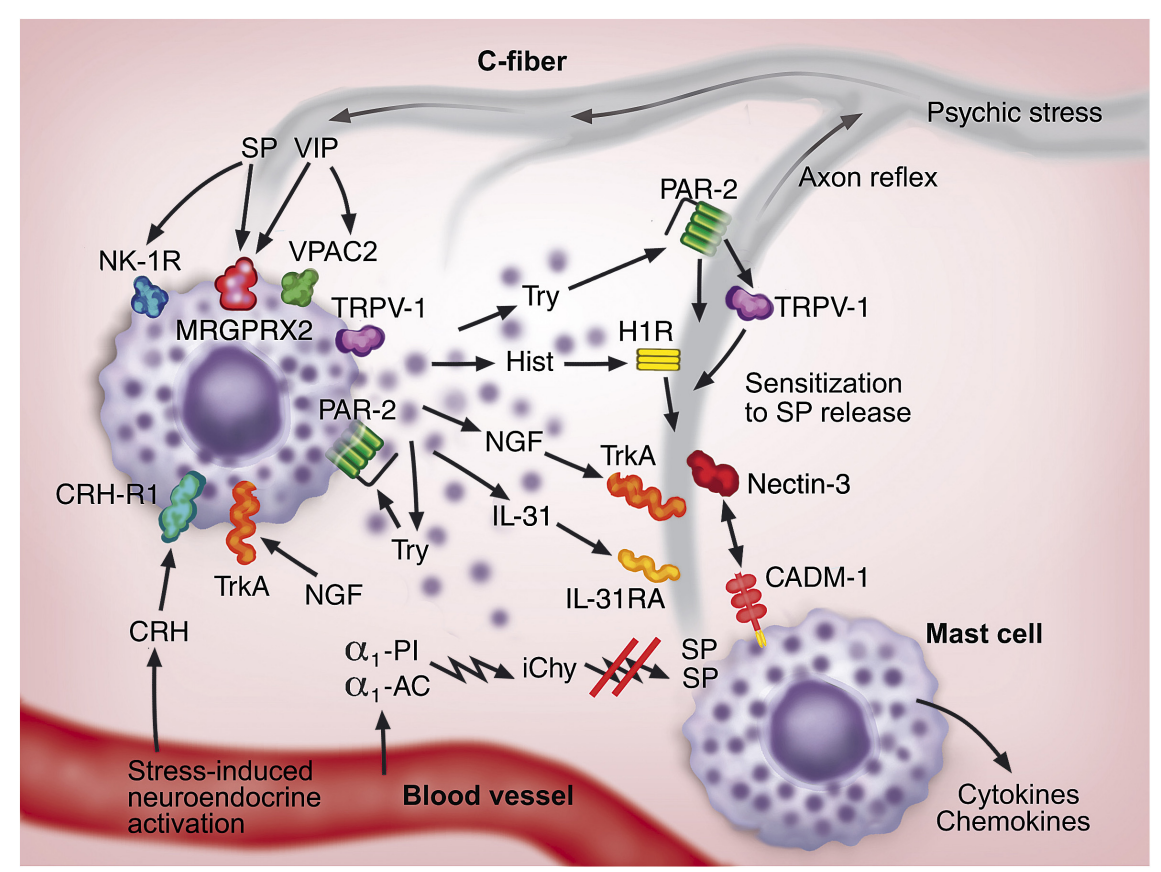

FIGURE 1 | A hypothetical model for the communication between mast cells (two mast cells shown in purple) and sensory nerves (shown in gray) in neurogenic inflammation in the skin. The neuroendocrine and neural systems are activated as a consequence of psychosocial stress. The signals traveling through C-fibers lead to the release of neuropeptides, substance P (SP) and vasoactive intestinal peptide (VIP), from C-fiber endings. The increased cutaneous blood flow conveys corticotropin-releasing hormone $(\mathrm{CRH})$ to the developing inflammation. These neuroendocrine factors activate mast cells through the receptors NK-1R, VPAC2, MRGPRX2, and CRH-R1. Tryptase (Try), histamine (Hist), NGF, IL-31 released from mast cells activate their corresponding receptors PAR-2, H1R, TrkA, and IL-31RA, respectively, on C-fibers. Furthermore, mast cells themselves are activated through PAR-2 and TrkA in an auto- or paracrine fashion. Mast cell-derived mediators activate C-fibers leading to the spread of signal, which can also take place through an axon reflex-related mechanism. NGF and IL-31 support the growth of C-fibers. Chymase released from mast cells is susceptible to the inactivation by serum protease inhibitors, $\alpha_{1}$-proteinase inhibitor $\left(\alpha_{1}\right.$-PI) and $\alpha_{1}$-antichymotrypsin $\left(\alpha_{1}-\mathrm{AC}\right)$, resulting in inactivated chymase (iChy) that cannot degrade and inactivate SP. PAR-2 can sensitize the capsaicin receptor (TRPV-1) in C-fibers enhancing SP and CGRP release. The intimate functional and morphologic communications between mast cells and C-fibers are further strengthened by the cell adhesion molecule-1 (CADM-1) on mast cells and nectin-3 on C-fibers. As a consequence of these multiple interactions, a feedforward loop is developed, which leads to increase in mast cells and C-fibers, development of vicious circle, and potentiation of neurogenic inflammation and itch. 
The interaction between nerve fibers and mast cells can be affected by molecules leading to decreased itch and inflammation. In the $\mathrm{NC} / \mathrm{Nga}$ mouse model of $\mathrm{AD}$, dorsal skin lesions develop spontaneously. The treatment of these lesions with intracutaneous injections of semaphorin-3A, a nerve repulsion factor, for 5 days followed by biopsing on day 11 (Yamaguchi et al., 2008) revealed a significant reduction in the clinical skin score and scratching behavior, decrease in PGP9. $5^{+}$nerve fibers in the epidermis, decrease in mast cell numbers, infiltrating $\mathrm{CD}^{+}{ }^{+} \mathrm{T}$ cells, IL-4 production, and epidermal thickness (Yamaguchi et al., 2008). In addition, oral administration of chymase inhibitor has been shown to ameliorate dermatitis (Watanabe et al., 2007) as well as scratching behavior in these NC/Nga mice (Terakawa et al., 2008).

In pruritus, the neuroendocrine signals may travel from the central nervous system to periphery and vice versa. MacQueen et al. (1989) showed in 80's that rats exposed to both audiovisual cue and antigen injection were conditioned to mast cell protease II release after reexposure to the audiovisual cue only. A sonic stress for $24 \mathrm{~h}$ in mice can induce degranulation of mast cells, changes in endothelium, increase in substance $\mathrm{P}^{+}$fibers and their contacts with mast cells, and increase in the expression of NGF in skin mast cells (Peters et al., 2005, 2011; Pavlovic et al., 2008). Furthermore, skin mast cells in rats can be activated by stress induced by immobilization (Singh et al., 1999). In summary, there is compelling in vivo-evidence that show activation of mast cells induced by stress.

In an $\mathrm{AD}$ model induced by IL-13 in mice, the scratching behavior evoked by itch associated with increase in PGP9.5 ${ }^{+}$, $\mathrm{CGRP}^{+}$, and TRPA- ${ }^{+}$(transient receptor potential ankyrin (1) nerves, mast cells, and particularly in TRPA- ${ }^{+}$mast cells. However, there was no increase in TRPV-1 in inflamed skin. In line with this, TRPA- $1^{+}$mast cells and nerves and the contacts between them were increased in the lesional skin of patients with AD (Oh et al., 2013). Therefore, this study emphasizes the role of TRPA-1 in itch associated with skin inflammation. In contrast to this, itch evoked by intradermal injections of $\beta 2$-microglobulin in mouse skin is related, at least in part, to TRPV $-1^{+}$primary sensory nerves (Andoh et al., 2017b). Furthermore, itch evoked by IL-31 injections in mice is related to both TRPV-1 and TRPA-1 using knockout mouse models (Cevikbas et al., 2014). In addition, itch induced in mice by lysophosphatidic acid-injections is related to both cation channels (Kittaka et al., 2017).

\section{REFERENCES}

Ackermann, L., and Harvima, I. T. (1998). Mast cells of psoriatic and atopic dermatitis skin are positive for TNF-alpha and their degranulation is associated with expression of ICAM-1 in the epidermis. Arch. Dermatol. Res. 290, 353-359. doi: 10.1007/s004030050317

Albisetti, G. W., Pagani, M., Platonova, E., Hosli, L., Johannssen, H. C., Fritschy, J. M., et al. (2019). Dorsal horn gastrin-releasing peptide expressing neurons transmit spinal itch but not pain signals. J. Neurosci. 39, 2238-2250. doi: 10.1523/JNEUROSCI.2559-18. 2019

Amadesi, S., Nie, J., Vergnolle, N., Cottrell, G. S., Grady, E. F., Trevisani, M., et al. (2004). Protease-activated receptor 2 sensitizes the capsaicin receptor transient

\section{CONCLUSION AND FUTURE CHALLENGES}

Despite thorough and extensive research on mast cells during the past decades, these cells still remain to be an intriguing, complex cell type present in our body-environment interfaces. Although mast cells are physiologically meant to stay alert and to react to potentially noxious agents and conditions, their reactions may turn harmful. In several disorders, their functions seem to increase itch, which is not always beneficial to the host.

The complex functional and morphologic interaction between mast cells and sensory nerves is summarized and illustrated in Figure 1. Psychic stress can aggravate itch in several skin diseases. Although the mechanism is not clear in detail, the activation of the systemic HPA axis and/or its equivalent in the skin as well as the activation of neural response can play a role in activating the neurogenic inflammation in the skin. As a consequence, several neuroendocrine mediators, including $\mathrm{CRH}$, substance $\mathrm{P}$ and $\mathrm{NGF}$, are released to the circulation and/or are produced locally in the skin. These mediators lead to activation of mast cells and release of their proinflammatory mediators that modify the inflammation of the skin disorder, often increasing itch. The mechanisms are complex owing to the intimate reciprocal communication between mast cells and sensory nerves resulting in increase in mast cell numbers and nerve fibers, development of a vicious circle, and exacerbation of neurogenic inflammation and pruritus.

Future research should aim at further elucidating the details of mast cell biology in different physiological and pathological skin conditions in humans. Here, it will be important to focus on the association of psychic stress with mast cell-neural functions in patients with psoriasis or atopic dermatitis under standardized stress conditions. We should also aim at more indepth understanding of mast cell heterogeneity and recruitment to the skin and how these may affect mast cell-neural responses in chronic pruritic disorders. In addition, the inhibitors of mast cell mediators or drugs preventing mast cell activation (Harvima et al., 2014) may provide new therapeutic options to treat distressing itch and thereby improve the quality of life of patients.

\section{AUTHOR CONTRIBUTIONS}

Both authors wrote and edited the text.

receptor potential vanilloid receptor 1 to induce hyperalgesia. J. Neurosci. 24, 4300-4312. doi: 10.1523/JNEUROSCI.5679-03.2004

Amatya, B., El-Nour, H., Holst, M., Theodorsson, E., and Nordlind, K. (2011). Expression of tachykinins and their receptors in plaque psoriasis with pruritus. Br. J. Dermatol. 164, 1023-1029. doi: 10.1111/j.1365-2133.2011.10241.x

Andoh, T., Harada, A., and Kuraishi, Y. (2017a). Involvement of leukotriene B4 released from keratinocytes in itch-associated response to intradermal interleukin-31 in mice. Acta Derm. Venereol. 97, 922-927. doi: 10.2340/ 00015555-2697

Andoh, T., Maki, T., Li, S., and Uta, D. (2017b). beta2-Microglobulin elicits itchrelated responses in mice through the direct activation of primary afferent neurons expressing transient receptor potential vanilloid 1. Eur. J. Pharmacol. 810, 134-140. doi: 10.1016/j.ejphar.2017.07.007 
Andoh, T., Katsube, N., Maruyama, M., and Kuraishi, Y. (2001). Involvement of leukotriene $\mathrm{B}(4)$ in substance P-induced itch-associated response in mice. J. Invest. Dermatol. 117, 1621-1626. doi: 10.1046/j.0022-202x.2001.01585.x

Andoh, T., and Kuraishi, Y. (1998). Intradermal leukotriene B4, but not prostaglandin E2, induces itch-associated responses in mice. Eur. J. Pharmacol. 353, 93-96. doi: 10.1016/S0014-2999(98)00440-3

Andoh, T., Takayama, Y., and Kuraishi, Y. (2014). Involvement of leukotriene B4 in dermatophyte-related itch in mice. Pharmacol. Rep. 66, 699-703. doi: $10.1016 /$ j.pharep.2014.01.003

Arck, P. C., Slominski, A., Theoharides, T. C., Peters, E. M., and Paus, R. (2006). Neuroimmunology of stress: skin takes center stage. J. Invest. Dermatol. 126, 1697-1704. doi: 10.1038/sj.jid.5700104

Azimi, E., Xia, J., and Lerner, E. A. (2016). Peripheral mechanisms of itch. Curr. Probl. Dermatol. 50, 18-23. doi: 10.1159/000446012

Back, S. K., Jeong, K. Y., Li, C., Lee, J., Lee, S. B., and Na, H. S. (2012). Chronically relapsing pruritic dermatitis in the rats treated as neonate with capsaicin; a potential rat model of human atopic dermatitis. J. Dermatol. Sci. 67, 111-119. doi: 10.1016/j.jdermsci.2012.05.006

Baraniuk, J. N. (2012). Rise of the sensors: nociception and pruritus. Curr. Allergy Asthma Rep. 12, 104-114. doi: 10.1007/s11882-012-0245-8

Basavaraj, K. H., Navya, M. A., and Rashmi, R. (2011). Stress and quality of life in psoriasis: an update. Int. J. Dermatol. 50, 783-792. doi: 10.1111/j.1365-4632. 2010.04844.x

Belghiti, M., Estevez-Herrera, J., Gimenez-Garzo, C., Gonzalez-Usano, A., Montoliu, C., Ferrer-Montiel, A., et al. (2013). Potentiation of the transient receptor potential vanilloid 1 channel contributes to pruritogenesis in a rat model of liver disease. J. Biol. Chem. 288, 9675-9685. doi: 10.1074/jbc.M113. 455162

Bigliardi-Qi, M., Sumanovski, L. T., Buchner, S., Rufli, T., and Bigliardi, P. L. (2004). Mu-opiate receptor and Beta-endorphin expression in nerve endings and keratinocytes in human skin. Dermatology 209, 183-189. doi: 10.1159/ 000079887

Biswas, A., Richards, J. E., Massaro, J., and Mahalingam, M. (2014). Mast cells in cutaneous tumors: innocent bystander or maestro conductor? Int. J. Dermatol. 53, 806-811. doi: 10.1111/j.1365-4632.2012.05745.x

Bo, L., Mork, S. J., and Nyland, H. (1992). An immunohistochemical study of mononuclear cells in meningiomas. Neuropathol. Appl. Neurobiol. 18, 548-558. doi: 10.1111/j.1365-2990.1992.tb00825.x

Bradding, P., Walls, A. F., and Holgate, S. T. (2006). The role of the mast cell in the pathophysiology of asthma. J. Allergy Clin. Immunol. 117, 1277-1284. doi: $10.1016 /$ j.jaci.2006.02.039

Caraffa, A., Conti, C., D Ovidio, C., Gallenga, C. E., Tettamanti, L., Mastrangelo, F., et al. (2018). New concepts in neuroinflammation: mast cells pro-inflammatory and anti-inflammatory cytokine mediators. J. Biol. Regul. Homeost. Agents 32, 449-454.

Carvalho, R. F., Nilsson, G., and Harvima, I. T. (2010). Increased mast cell expression of PAR-2 in skin inflammatory diseases and release of IL-8 upon PAR-2 activation. Exp. Dermatol. 19, 117-122. doi: 10.1111/j.1600-0625.2009. 00998.x

Caughey, G. H., Leidig, F., Viro, N. F., and Nadel, J. A. (1988). Substance P and vasoactive intestinal peptide degradation by mast cell tryptase and chymase. J. Pharmacol. Exp. Ther. 244, 133-137.

Cevikbas, F., Wang, X., Akiyama, T., Kempkes, C., Savinko, T., Antal, A., et al. (2014). A sensory neuron-expressed IL-31 receptor mediates T helper celldependent itch: involvement of TRPV1 and TRPA. J. Allergy Clin. Immunol. 133, 448-460. doi: 10.1016/j.jaci.2013.10.048

Chang, S. E., Han, S. S., Jung, H. J., and Choi, J. H. (2007). Neuropeptides and their receptors in psoriatic skin in relation to pruritus. Br. J. Dermatol. 156, 1272-1277. doi: 10.1111/j.1365-2133.2007.07935.x

Chen, Y., Fang, Q., Wang, Z., Zhang, J. Y., MacLeod, A. S., Hall, R. P., et al. (2016). Transient receptor potential vanilloid 4 ion channel functions as a pruriceptor in epidermal keratinocytes to evoke histaminergic itch. J. Biol. Chem. 291, 10252-10262. doi: 10.1074/jbc.M116.716464

Choi, H., Kim, D. J., Nam, S., Lim, S., Hwang, J. S., Park, K. S., et al. (2018). Manifestation of atopic dermatitis-like skin in TNCB-induced NC/Nga mice is ameliorated by topical treatment of substance $\mathrm{P}$, possibly through blockade of allergic inflammation. Exp. Dermatol. 27, 396-402. doi: 10.1111/exd.13421
Church, M. K., Kolkhir, P., Metz, M., and Maurer, M. (2018). The role and relevance of mast cells in urticaria. Immunol. Rev. 282, 232-247. doi: 10.1111/imr.12632

Conti, P., Caraffa, A., Kritas, S. K., Ronconi, G., Lessiani, G., Toniato, E., et al. (2017). Mast cell, pro-inflammatory and anti-inflammatory: Jekyll and Hyde, the story continues. J. Biol. Regul. Homeost. Agents 31, 263-267.

da Silva, E. Z., Jamur, M. C., and Oliver, C. (2014). Mast cell function: a new vision of an old cell. J. Histochem. Cytochem. 62, 698-738. doi: 10.1369/ 0022155414545334

Diaconu, N. C., Kaminska, R., Naukkarinen, A., Harvima, R. J., and Harvima, I. T. (2007). The increase in tryptase- and chymase-positive mast cells is associated with partial inactivation of chymase and increase in protease inhibitors in basal cell carcinoma. J. Eur. Acad. Dermatol. Venereol. 21, 908-915. doi: 10.1111/j. 1468-3083.2006.02100.x

Dillon, S. R., Sprecher, C., Hammond, A., Bilsborough, J., Rosenfeld-Franklin, M., Presnell, S. R., et al. (2004). Interleukin 31, a cytokine produced by activated $\mathrm{T}$ cells, induces dermatitis in mice. Nat. Immunol. 5, 752-760. doi: 10.1038/ ni1084

Dunford, P. J., Williams, K. N., Desai, P. J., Karlsson, L., McQueen, D., and Thurmond, R. L. (2007). Histamine H4 receptor antagonists are superior to traditional antihistamines in the attenuation of experimental pruritus. J. Allergy Clin. Immunol. 119, 176-183. doi: 10.1016/j.jaci.2006.08.034

Eedy, D. J., Johnston, C. F., Shaw, C., and Buchanan, K. D. (1991). Neuropeptides in psoriasis: an immunocytochemical and radioimmunoassay study. J. Invest. Dermatol. 96, 434-438. doi: 10.1111/1523-1747.ep12469898

Feld, M., Garcia, R., Buddenkotte, J., Katayama, S., Lewis, K., Muirhead, G., et al. (2016). The pruritus- and TH2-associated cytokine IL-31 promotes growth of sensory nerves. J. Allergy Clin. Immunol. 138, 500.e24-508.e24. doi: 10.1016/j. jaci.2016.02.020

Fischer, M., Harvima, I. T., Carvalho, R. F., Moller, C., Naukkarinen, A., Enblad, G., et al. (2006). Mast cell CD30 ligand is upregulated in cutaneous inflammation and mediates degranulation-independent chemokine secretion. J. Clin. Invest. 116, 2748-2756. doi: 10.1172/JCI24274

Fjellner, B., and Hägermark, O. (1981). Studies on pruritogenic and histaminereleasing effects of some putative peptide neurotransmitters. Acta Derm. Venereol. 61, 245-250.

Franconi, G. M., Graf, P. D., Lazarus, S. C., Nadel, J. A., and Caughey, G. H. (1989). Mast cell tryptase and chymase reverse airway smooth muscle relaxation induced by vasoactive intestinal peptide in the ferret. J. Pharmacol. Exp. Ther. 248, 947-951.

Fujisawa, D., Kashiwakura, J., Kita, H., Kikukawa, Y., Fujitani, Y., Sasaki-Sakamoto, T., et al. (2014). Expression of Mas-related gene X2 on mast cells is upregulated in the skin of patients with severe chronic urticaria. J. Allergy Clin. Immunol. 134, 622.e9-633.e9. doi: 10.1016/j.jaci.2014.05.004

Furuno, T., Hagiyama, M., Sekimura, M., Okamoto, K., Suzuki, R., Ito, A., et al. (2012). Cell adhesion molecule 1 (CADM1) on mast cells promotes interaction with dorsal root ganglion neurites by heterophilic binding to nectin. J. Neuroimmunol. 250, 50-58. doi: 10.1016/j.jneuroim.2012.05.016

Gallenga, C. E., Pandolfi, F., Caraffa, A., Kritas, S. K., Ronconi, G., Toniato, E., et al. (2019). Interleukin-1 family cytokines and mast cells: activation and inhibition. J. Biol. Regul. Homeost. Agents 33, 1-6.

Greaves, M. W. (2010). Pathogenesis and treatment of pruritus. Curr. Allergy Asthma Rep. 10, 236-242. doi: 10.1007/s11882-010-0117-z

Grimbaldeston, M. A., Simpson, A., Finlay-Jones, J. J., and Hart, P. H. (2003). The effect of ultraviolet radiation exposure on the prevalence of mast cells in human skin. Br. J. Dermatol. 148, 300-306. doi: 10.1046/j.1365-2133.2003.05113.x

Groneberg, D. A., Serowka, F., Peckenschneider, N., Artuc, M., Grutzkau, A., Fischer, A., et al. (2005). Gene expression and regulation of nerve growth factor in atopic dermatitis mast cells and the human mast cell line. J. Neuroimmunol. 161, 87-92. doi: 10.1016/j.jneuroim.2004.12.019

Gruber, B. L., Baeza, M. L., Marchese, M. J., Agnello, V., and Kaplan, A. P. (1988). Prevalence and functional role of anti-IgE autoantibodies in urticarial syndromes. J. Invest. Dermatol. 90, 213-217. doi: 10.1111/1523-1747. ep12462239

Gupta, K., and Harvima, I. T. (2018). Mast cell-neural interactions contribute to pain and itch. Immunol. Rev. 282, 168-187. doi: 10.1111/imr.12622

Gurish, M. F., and Austen, K. F. (2001). The diverse roles of mast cells. J. Exp. Med. 194, F1-F5. 
Hägermark, O., Hökfelt, T., and Pernow, B. (1978). Flare and itch induced by substance P in human skin. J. Invest. Dermatol. 71, 233-235. doi: 10.1111/15231747.ep12515092

Hagiyama, M., Inoue, T., Furuno, T., Ino, T., Itami, S., Nakanishi, M., et al. (2013). Increased expression of cell adhesion molecule 1 by mast cells as a cause of enhanced nerve-mast cell interaction in a hapten-induced mouse model of atopic dermatitis. Br. J. Dermatol. 168, 771-778. doi: 10.1111/bjd.12108

Haimakainen, S., Kaukinen, A. P., Suttle, M. M., Pelkonen, J., and Harvima, I. T. (2017). CD40 ligand is increased in mast cells in psoriasis and actinic keratosis but less so in epithelial skin carcinomas. Cancer Invest. 35, 143-151. doi: 10.1080/07357907.2017.1289216

Harvima, I. T., Levi-Schaffer, F., Draber, P., Friedman, S., Polakovicova, I., Gibbs, B. F., et al. (2014). Molecular targets on mast cells and basophils for novel therapies. J. Allergy Clin. Immunol. 134, 530-544. doi: 10.1016/j.jaci.2014.03. 007

Harvima, I. T., and Nilsson, G. (2012). Stress, the neuroendocrine system and mast cells: current understanding of their role in psoriasis. Expert Rev. Clin. Immunol. 8, 235-241. doi: 10.1586/eci.12.1

Harvima, I. T., Nilsson, G., Suttle, M. M., and Naukkarinen, A. (2008). Is there a role for mast cells in psoriasis? Arch. Dermatol. Res. 300, 461-478. doi: 10.1007/ s00403-008-0874- $\mathrm{x}$

Hashimoto, Y., Arai, I., Tanaka, M., and Nakaike, S. (2005). Prostaglandin D2 inhibits IgE-mediated scratching by suppressing histamine release from mast cells. J. Pharmacol. Sci. 98, 90-93. doi: 10.1254/jphs.sc0040209

Hawro, T., Saluja, R., Weller, K., Altrichter, S., Metz, M., and Maurer, M. (2014). Interleukin-31 does not induce immediate itch in atopic dermatitis patients and healthy controls after skin challenge. Allergy 69, 113-117. doi: 10.1111/all. 12316

Hide, M., Francis, D. M., Grattan, C. E., Hakimi, J., Kochan, J. P., and Greaves, M. W. (1993). Autoantibodies against the high-affinity IgE receptor as a cause of histamine release in chronic urticaria. N. Engl. J. Med. 328, 1599-1604. doi: 10.1056/NEJM199306033282204

Horigome, K., Pryor, J. C., Bullock, E. D., and Johnson, E. M. Jr. (1993). Mediator release from mast cells by nerve growth factor. Neurotrophin specificity and receptor mediation. J. Biol. Chem. 268, 14881-14887.

Horsmanheimo, L., Harvima, I. T., Järvikallio, A., Harvima, R. J., Naukkarinen, A., and Horsmanheimo, M. (1994). Mast cells are one major source of interleukin4 in atopic dermatitis. Br. J. Dermatol. 131, 348-353. doi: 10.1111/j.1365-2133. 1994.tb08522.x

Hu, G., Wang, S., and Cheng, P. (2018). Tumor-infiltrating tryptase(+) mast cells predict unfavorable clinical outcome in solid tumors. Int. J. Cancer 142, 813-821. doi: 10.1002/ijc.31099

Huttunen, M., Harvima, I. T., Ackermann, L., Harvima, R. J., Naukkarinen, A., and Horsmanheimo, M. (1996). Neuropeptide- and capsaicin-induced histamine release in skin monitored with the microdialysis technique. Acta Derm. Venereol. 76, 205-209.

Ilves, T., and Harvima, I. T. (2015). Decrease in chymase activity is associated with increase in IL-6 expression in mast cells in atopic dermatitis. Acta Derm. Venereol. 95, 411-416. doi: 10.2340/00015555-1979

Ilves, T., Tiitu, V., Suttle, M. M., Saarinen, J. V., and Harvima, I. T. (2015). Epidermal expression of filaggrin/profilaggrin is decreased in atopic dermatitis: reverse association with mast cell tryptase and IL- 6 but not with clinical severity. Dermatitis 26, 260-267. doi: 10.1097/DER.00000000000 00143

Järvikallio, A., Harvima, I. T., and Naukkarinen, A. (2003). Mast cells, nerves and neuropeptides in atopic dermatitis and nummular eczema. Arch. Dermatol. Res. 295, 2-7. doi: 10.1007/s00403-002-0378-Z

Järvikallio, A., Naukkarinen, A., Harvima, I. T., Aalto, M. L., and Horsmanheimo, M. (1997). Quantitative analysis of tryptase- and chymase-containing mast cells in atopic dermatitis and nummular eczema. Br. J. Dermatol. 136, 871-877. doi: 10.1111/j.1365-2133.1997.tb03927.x

Kempkes, C., Buddenkotte, J., Cevikbas, F., Buhl, T., and Steinhoff, M. (2014). "Role of PAR-2 in neuroimmune communication and itch," in Itch: Mechanisms and Treatment, eds E. Carstens and T. Akiyama (Boca Raton, FL: CRC Press).

Kim, J. E., Cho, D. H., Kim, H. S., Kim, H. J., Lee, J. Y., Cho, B. K., et al. (2007). Expression of the corticotropin-releasing hormone-proopiomelanocortin axis in the various clinical types of psoriasis. Exp. Dermatol. 16, 104-109. doi: $10.1111 / j .1600-0625.2006 .00509 . x$
Kim, M. S., Kim, Y. K., Lee, D. H., Seo, J. E., Cho, K. H., Eun, H. C., et al. (2009). Acute exposure of human skin to ultraviolet or infrared radiation or heat stimuli increases mast cell numbers and tryptase expression in human skin in vivo. $B r$. J. Dermatol. 160, 393-402. doi: 10.1111/j.1365-2133.2008.08838.x

Kitagaki, H., Fujisawa, S., Watanabe, K., Hayakawa, K., and Shiohara, T. (1995). Immediate-type hypersensitivity response followed by a late reaction is induced by repeated epicutaneous application of contact sensitizing agents in mice. J. Invest. Dermatol. 105, 749-755. doi: 10.1111/1523-1747.ep12325538

Kittaka, H., Uchida, K., Fukuta, N., and Tominaga, M. (2017). Lysophosphatidic acid-induced itch is mediated by signalling of LPA5 receptor, phospholipase D and TRPA1/TRPV. J. Physiol. 595, 2681-2698. doi: 10.1113/JP273961

Kou, K., Nakamura, F., Aihara, M., Chen, H., Seto, K., Komori-Yamaguchi, J., et al. (2012). Decreased expression of semaphorin-3A, a neurite-collapsing factor, is associated with itch in psoriatic skin. Acta Derm. Venereol. 92, 521-528. doi: $10.2340 / 00015555-1350$

Kubanov, A. A., Katunina, O. R., and Chikin, V. V. (2015). Expression of neuropeptides, neurotrophins, and neurotransmitters in the skin of patients with atopic dermatitis and psoriasis. Bull. Exp. Biol. Med. 159, 318-322. doi: 10.1007/s10517-015-2951-4

Kulka, M., Sheen, C. H., Tancowny, B. P., Grammer, L. C., and Schleimer, R. P. (2008). Neuropeptides activate human mast cell degranulation and chemokine production. Immunology 123, 398-410. doi: 10.1111/j.1365-2567.2007.02705.x

Kuramoto, T., Yokoe, M., Tanaka, D., Yuri, A., Nishitani, A., Higuchi, Y., et al. (2015). Atopic dermatitis-like skin lesions with IgE hyperproduction and pruritus in KFRS4/Kyo rats. J. Dermatol. Sci. 80, 116-123. doi: 10.1016/j. jdermsci.2015.09.005

LaMotte, R. H., Dong, X., and Ringkamp, M. (2014). Sensory neurons and circuits mediating itch. Nat. Rev. Neurosci. 15, 19-31. doi: 10.1038/nrn3641

Liang, Y., Marcusson, J. A., Jacobi, H. H., Haak-Frendscho, M., and Johansson, O. (1998). Histamine-containing mast cells and their relationship to NGFrimmunoreactive nerves in prurigo nodularis: a reappraisal. J. Cutan. Pathol. 25, 189-198. doi: 10.1111/j.1600-0560.1998.tb01718.x

Lundeen, K. A., Sun, B., Karlsson, L., and Fourie, A. M. (2006). Leukotriene B4 receptors BLT1 and BLT2: expression and function in human and murine mast cells. J. Immunol. 177, 3439-3447. doi: 10.4049/jimmunol.177.5.3439

MacQueen, G., Marshall, J., Perdue, M., Siegel, S., and Bienenstock, J. (1989). Pavlovian conditioning of rat mucosal mast cells to secrete rat mast cell protease II. Science 243, 83-85. doi: 10.1126/science.2911721

Matusiak, L., Szczech, J., Kaaz, K., Lelonek, E., and Szepietowski, J. C. (2018). Clinical characteristics of pruritus and pain in patients with Hidradenitis Suppurativa. Acta Derm. Venereol. 98, 191-194. doi: 10.2340/00015555-2815

McNeil, B. D., Pundir, P., Meeker, S., Han, L., Undem, B. J., Kulka, M., et al. (2015). Identification of a mast-cell-specific receptor crucial for pseudo-allergic drug reactions. Nature 519, 237-241. doi: 10.1038/nature14022

Meng, J., Moriyama, M., Feld, M., Buddenkotte, J., Buhl, T., Szollosi, A., et al. (2018). New mechanism underlying IL-31-induced atopic dermatitis. J. Allergy Clin. Immunol. 141, 1677.e8-1689.e8. doi: 10.1016/j.jaci.2017.12.1002

Mills, K. C., Kwatra, S. G., Feneran, A. N., Pearce, D. J., Williford, P. M., D'Agostino, R. B., et al. (2012). Itch and pain in nonmelanoma skin cancer: pain as an important feature of cutaneous squamous cell carcinoma. Arch. Dermatol. 148, 1422-1423. doi: 10.1001/archdermatol.2012.3104

Moiseeva, E. P., Roach, K. M., Leyland, M. L., and Bradding, P. (2013). CADM1 is a key receptor mediating human mast cell adhesion to human lung fibroblasts and airway smooth muscle cells. PLoS One 8:e61579. doi: 10.1371/journal.pone. 0061579

Murakami, M., Matsumoto, R., Urade, Y., Austen, K. F., and Arm, J. P. (1995). c-kit ligand mediates increased expression of cytosolic phospholipase A2, prostaglandin endoperoxide synthase-1, and hematopoietic prostaglandin D2 synthase and increased IgE-dependent prostaglandin D2 generation in immature mouse mast cells. J. Biol. Chem. 270, 3239-3246. doi: 10.1074/jbc. 270.7.3239

Murota, H., and Katayama, I. (2017). Exacerbating factors of itch in atopic dermatitis. Allergol. Int. 66, 8-13. doi: 10.1016/j.alit.2016.10.005

Nakamura, M., Toyoda, M., and Morohashi, M. (2003). Pruritogenic mediators in psoriasis vulgaris: comparative evaluation of itch-associated cutaneous factors. Br. J. Dermatol. 149, 718-730. doi: 10.1046/j.1365-2133.2003.05586.x

Nakamura, N., Tamagawa-Mineoka, R., Yasuike, R., Masuda, K., Matsunaka, H., Murakami, Y., et al. (2019). Stratum corneum interleukin-33 expressions 
correlate with the degree of lichenification and pruritus in atopic dermatitis lesions. Clin. Immunol. 201, 1-3. doi: 10.1016/j.clim.2019.02.006

Nattkemper, L. A., Martinez-Escala, M. E., Gelman, A. B., Singer, E. M., Rook, A. H., Guitart, J., et al. (2016). Cutaneous T-cell Lymphoma and Pruritus: the expression of IL-31 and its receptors in the skin. Acta Derm. Venereol. 96, 894-898. doi: 10.2340/00015555-2417

Naukkarinen, A., Harvima, I., Paukkonen, K., Aalto, M. L., and Horsmanheimo, M. (1993). Immunohistochemical analysis of sensory nerves and neuropeptides, and their contacts with mast cells in developing and mature psoriatic lesions. Arch. Dermatol. Res. 285, 341-346. doi: 10.1007/bf00371834

Naukkarinen, A., Harvima, I. T., Aalto, M. L., Harvima, R. J., and Horsmanheimo, M. (1991). Quantitative analysis of contact sites between mast cells and sensory nerves in cutaneous psoriasis and lichen planus based on a histochemical double staining technique. Arch. Dermatol. Res. 283, 433-437. doi: 10.1007/ bf00371778

Naukkarinen, A., Nickoloff, B. J., and Farber, E. M. (1989). Quantification of cutaneous sensory nerves and their substance $\mathrm{P}$ content in psoriasis. J. Invest. Dermatol. 92, 126-129. doi: 10.1111/1523-1747.ep13071340

Nilsson, G., Forsberg-Nilsson, K., Xiang, Z., Hallböök, F., Nilsson, K., and Metcalfe, D. D. (1997). Human mast cells express functional TrkA and are a source of nerve growth factor. Eur. J. Immunol. 27, 2295-2301. doi: 10.1002/eji. 1830270925

Niyonsaba, F., Ushio, H., Hara, M., Yokoi, H., Tominaga, M., Takamori, K., et al. (2010). Antimicrobial peptides human beta-defensins and cathelicidin LL-37 induce the secretion of a pruritogenic cytokine IL-31 by human mast cells. J. Immunol. 184, 3526-3534. doi: 10.4049/jimmunol.0900712

Oh, M. H., Oh, S. Y., Lu, J., Lou, H., Myers, A. C., Zhu, Z., et al. (2013). TRPA1dependent pruritus in IL-13-induced chronic atopic dermatitis. J. Immunol. 191, 5371-5382. doi: 10.4049/jimmunol.1300300

Ohsawa, Y., and Hirasawa, N. (2014). The role of histamine H1 and H4 receptors in atopic dermatitis: from basic research to clinical study. Allergol. Int. 63, 533-542. doi: 10.2332/allergolint.13-RA-0675

Owen, J., Punt, J., and Stranford, S. (eds) (2013). Kuby Immunology, 7th Edn. New York, NY: Freeman W. H. \& Company.

Pavlovic, S., Daniltchenko, M., Tobin, D. J., Hagen, E., Hunt, S. P., Klapp, B. F., et al. (2008). Further exploring the brain-skin connection: stress worsens dermatitis via substance P-dependent neurogenic inflammation in mice. J. Invest. Dermatol. 128, 434-446. doi: 10.1038/sj.jid.5701079

Peters, E. M., Kuhlmei, A., Tobin, D. J., Muller-Rover, S., Klapp, B. F., and Arck, P. C. (2005). Stress exposure modulates peptidergic innervation and degranulates mast cells in murine skin. Brain Behav. Immun. 19, 252-262. doi: 10.1016/j.bbi.2004.08.005

Peters, E. M., Liezmann, C., Spatz, K., Daniltchenko, M., Joachim, R., GimenezRivera, A., et al. (2011). Nerve growth factor partially recovers inflamed skin from stress-induced worsening in allergic inflammation. J. Invest. Dermatol. 131, 735-743. doi: 10.1038/jid.2010.317

Peters, E. M., Michenko, A., Kupfer, J., Kummer, W., Wiegand, S., Niemeier, V., et al. (2014). Mental stress in atopic dermatitis-neuronal plasticity and the cholinergic system are affected in atopic dermatitis and in response to acute experimental mental stress in a randomized controlled pilot study. PLoS One 9:e113552. doi: 10.1371/journal.pone.0113552

Petra, A. I., Tsilioni, I., Taracanova, A., Katsarou-Katsari, A., and Theoharides, T. C. (2018). Interleukin 33 and interleukin 4 regulate interleukin 31 gene expression and secretion from human laboratory of allergic diseases 2 mast cells stimulated by substance P and/or immunoglobulin E. Allergy Asthma Proc. 39, 153-160. doi: 10.2500/aap.2018.38.4105

Puccetti, A., Bason, C., Simeoni, S., Millo, E., Tinazzi, E., Beri, R., et al. (2005). In chronic idiopathic urticaria autoantibodies against Fc epsilonRII/CD23 induce histamine release via eosinophil activation. Clin. Exp. Allergy 35, 1599-1607. doi: 10.1111/j.1365-2222.2005.02380.x

Rajabi, P., Bagheri, A., and Hani, M. (2017). Intratumoral and peritumoral mast cells in malignant melanoma: an immunohistochemical study. Adv. Biomed. Res. 6:39. doi: 10.4103/2277-9175.204592

Ribatti, D., Ennas, M. G., Vacca, A., Ferreli, F., Nico, B., Orru, S., et al. (2003a). Tumor vascularity and tryptase-positive mast cells correlate with a poor prognosis in melanoma. Eur. J. Clin. Invest. 33, 420-425. doi: 10.1046/j.13652362.2003.01152.x
Ribatti, D., Vacca, A., Ria, R., Marzullo, A., Nico, B., Filotico, R., et al. (2003b). Neovascularisation, expression of fibroblast growth factor-2, and mast cells with tryptase activity increase simultaneously with pathological progression in human malignant melanoma. Eur. J. Cancer 39, 666-674. doi: 10.1016/s09598049(02)00150-8

Rossbach, K., Nassenstein, C., Gschwandtner, M., Schnell, D., Sander, K., Seifert, R., et al. (2011). Histamine H1, H3 and H4 receptors are involved in pruritus. Neuroscience 190, 89-102. doi: 10.1016/j.neuroscience.2011.06.002

Saadalla, A. M., Osman, A., Gurish, M. F., Dennis, K. L., Blatner, N. R., Pezeshki, A., et al. (2018). Mast cells promote small bowel cancer in a tumor stage-specific and cytokine-dependent manner. Proc. Natl. Acad. Sci. U.S.A. 115, 1588-1592. doi: 10.1073 /pnas. 1716804115

Saarinen, J. V., Harvima, R. J., Naukkarinen, A., Horsmanheimo, M., and Harvima, I. T. (2001). The release of histamine is associated with the inactivation of mast cell chymase during immediate allergic wheal reaction in the skin. Clin. Exp. Allergy 31, 593-601. doi: 10.1046/j.1365-2222.2001.01030.x

Satpathy, S. R., Jala, V. R., Bodduluri, S. R., Krishnan, E., Hegde, B., Hoyle, G. W., et al. (2015). Crystalline silica-induced leukotriene B4-dependent inflammation promotes lung tumour growth. Nat. Commun. 6:7064. doi: 10 . 1038/ncomms 8064

Savin, J. A. (1998). How should we define itching? J. Am. Acad. Dermatol. 39, 268-269. doi: 10.1016/s0190-9622(98)70087-8

Schmetzer, O., Lakin, E., Topal, F. A., Preusse, P., Freier, D., Church, M. K., et al. (2018). IL-24 is a common and specific autoantigen of IgE in patients with chronic spontaneous urticaria. J. Allergy Clin. Immunol. 142, 876-882. doi: 10.1016/j.jaci.2017.10.035

Shim, W. S., Tak, M. H., Lee, M. H., Kim, M., Kim, M., Koo, J. Y., et al. (2007). TRPV1 mediates histamine-induced itching via the activation of phospholipase A2 and 12-lipoxygenase. J. Neurosci. 27, 2331-2337. doi: 10.1523/JNEUROSCI. 4643-06.2007

Siiskonen, H., Poukka, M., Bykachev, A., Tyynelä-Korhonen, K., Sironen, R., Pasonen-Seppänen, S., et al. (2015). Low numbers of tryptase + and chymase+ mast cells associated with reduced survival and advanced tumor stage in melanoma. Melanoma Res. 25, 479-485. doi: 10.1097/CMR.0000000000000192

Singh, L. K., Pang, X., Alexacos, N., Letourneau, R., and Theoharides, T. C. (1999). Acute immobilization stress triggers skin mast cell degranulation via corticotropin releasing hormone, neurotensin, and substance P: a link to neurogenic skin disorders. Brain Behav. Immun. 13, 225-239. doi: 10.1006/brbi. 1998.0541

Sommer, F., Hensen, P., Bockenholt, B., Metze, D., Luger, T. A., and Ständer, S. (2007). Underlying diseases and co-factors in patients with severe chronic pruritus: a 3-year retrospective study. Acta Derm. Venereol. 87, 510-516. doi: 10.2340/00015555-0320

Sonkoly, E., Muller, A., Lauerma, A. I., Pivarcsi, A., Soto, H., Kemeny, L., et al. (2006). IL-31: a new link between T cells and pruritus in atopic skin inflammation. J. Allergy Clin. Immunol. 117, 411-417. doi: 10.1016/j.jaci.2005. 10.033

Spinnler, K., Frohlich, T., Arnold, G. J., Kunz, L., and Mayerhofer, A. (2011). Human tryptase cleaves pro-nerve growth factor (pro-NGF): hints of local, mast cell-dependent regulation of NGF/pro-NGF action. J. Biol. Chem. 286, 31707-31713. doi: 10.1074/jbc.M111.233486

Ständer, S., Moormann, C., Schumacher, M., Buddenkotte, J., Artuc, M., Shpacovitch, V., et al. (2004). Expression of vanilloid receptor subtype 1 in cutaneous sensory nerve fibers, mast cells, and epithelial cells of appendage structures. Exp. Dermatol. 13, 129-139. doi: 10.1111/j.0906-6705.2004.0178.x

Ständer, S., Ständer, H., Seeliger, S., Luger, T. A., and Steinhoff, M. (2007a). Topical pimecrolimus and tacrolimus transiently induce neuropeptide release and mast cell degranulation in murine skin. Br. J. Dermatol. 156, 1020-1026. doi: 10.1111/j.1365-2133.2007.07813.x

Ständer, S., Weisshaar, E., Mettang, T., Szepietowski, J. C., Carstens, E., Ikoma, A., et al. (2007b). Clinical classification of itch: a position paper of the International Forum for the Study of Itch. Acta Derm. Venereol. 87, 291-294. doi: 10.2340/ 00015555-0305

Steinhoff, M., Neisius, U., Ikoma, A., Fartasch, M., Heyer, G., Skov, P. S., et al. (2003). Proteinase-activated receptor-2 mediates itch: a novel pathway for pruritus in human skin. J. Neurosci. 23, 6176-6180. doi: 10.1523/JNEUROSCI. 23-15-06176.2003 
Suarez, A. L., Feramisco, J. D., Koo, J., and Steinhoff, M. (2012). Psychoneuroimmunology of psychological stress and atopic dermatitis: pathophysiologic and therapeutic updates. Acta Derm. Venereol. 92, 7-15. doi: 10.2340/00015555-1188

Subramanian, H., Gupta, K., and Ali, H. (2016). Roles of Mas-related G proteincoupled receptor X2 on mast cell-mediated host defense, pseudoallergic drug reactions, and chronic inflammatory diseases. J. Allergy Clin. Immunol. 138, 700-710. doi: 10.1016/j.jaci.2016.04.051

Sugimoto, Y., Umakoshi, K., Nojiri, N., and Kamei, C. (1998). Effects of histamine H1 receptor antagonists on compound 48/80-induced scratching behavior in mice. Eur. J. Pharmacol. 351, 1-5. doi: 10.1016/s0014-2999(98)00288-x

Szepietowski, J. C., and Reich, A. (2016). Pruritus in psoriasis: an update. Eur. J. Pain 20, 41-46. doi: 10.1002/ejp.768

Talagas, M., Lebonvallet, N., Leschiera, R., Marcorelles, P., and Misery, L. (2018). What about physical contacts between epidermal keratinocytes and sensory neurons? Exp. Dermatol. 27, 9-13. doi: 10.1111/exd.13411

Taneda, K., Tominaga, M., Negi, O., Tengara, S., Kamo, A., Ogawa, H., et al. (2011). Evaluation of epidermal nerve density and opioid receptor levels in psoriatic itch. Br. J. Dermatol. 165, 277-284. doi: 10.1111/j.1365-2133.2011.10347.x

Taracanova, A., Alevizos, M., Karagkouni, A., Weng, Z., Norwitz, E., Conti, P., et al. (2017). SP and IL-33 together markedly enhance TNF synthesis and secretion from human mast cells mediated by the interaction of their receptors. Proc. Natl. Acad. Sci. U.S.A. 114, E4002-E4009. doi: 10.1073/pnas.1524845114

Taracanova, A., Tsilioni, I., Conti, P., Norwitz, E. R., Leeman, S. E., and Theoharides, T. C. (2018). Substance P and IL-33 administered together stimulate a marked secretion of IL-1beta from human mast cells, inhibited by methoxyluteolin. Proc. Natl. Acad. Sci. U.S.A. 115, E9381-E9390. doi: 10.1073/ pnas. 1810133115

Terakawa, M., Fujieda, Y., Tomimori, Y., Muto, T., Tanaka, T., Maruoka, H., et al. (2008). Oral chymase inhibitor SUN13834 ameliorates skin inflammation as well as pruritus in mouse model for atopic dermatitis. Eur. J. Pharmacol. 601, 186-191. doi: 10.1016/j.ejphar.2008.10.040

Tettamanti, L., Kritas, S. K., Gallenga, C. E., D’Ovidio, C., Mastrangelo, F., Ronconi, G., et al. (2018). IL-33 mediates allergy through mast cell activation: potential inhibitory effect of certain cytokines. J. Biol. Regul. Homeost. Agents 32, 10611065.

Theoharides, T. C., Donelan, J., Kandere-Grzybowska, K., and Konstantinidou, A. (2005). The role of mast cells in migraine pathophysiology. Brain Res. Brain Res. Rev. 49, 65-76. doi: 10.1016/j.brainresrev.2004.11.006

Theoharides, T. C., and Kavalioti, M. (2018). Stress, inflammation and natural treatments. J. Biol. Regul. Homeost. Agents 32, 1345-1347.

Tobin, D., Nabarro, G., Baart de la Faille, H., van Vloten, W. A., van der Putte, S. C., and Schuurman, H. J. (1992). Increased number of immunoreactive nerve fibers in atopic dermatitis. J. Allergy Clin. Immunol. 90, 613-622. doi: 10.1097/01206501-199306000-00026

Tomimori, Y., Muto, T., Fukami, H., Saito, K., Horikawa, C., Tsuruoka, N., et al. (2002). Mast cell chymase regulates dermal mast cell number in mice. Biochem. Biophys. Res. Commun. 290, 1478-1482. doi: 10.1006/bbrc.2002.6365

Tominaga, M., and Takamori, K. (2014). Itch and nerve fibers with special reference to atopic dermatitis: therapeutic implications. J. Dermatol. 41, 205-212. doi: 10.1111/1346-8138.12317

Tominaga, M., Tengara, S., Kamo, A., Ogawa, H., and Takamori, K. (2009). Psoralen-ultraviolet A therapy alters epidermal Sema3A and NGF levels and modulates epidermal innervation in atopic dermatitis. J. Dermatol. Sci. 55, 40-46. doi: 10.1016/j.jdermsci.2009. 03.007

Toth-Jakatics, R., Jimi, S., Takebayashi, S., and Kawamoto, N. (2000). Cutaneous malignant melanoma: correlation between neovascularization and peritumor accumulation of mast cells overexpressing vascular endothelial growth factor. Hum. Pathol. 31, 955-960. doi: 10.1053/hupa.2000.16658

Tunon de Lara, J. M., Okayama, Y., McEuen, A. R., Heusser, C. H., Church, M. K., and Walls, A. F. (1994). Release and inactivation of interleukin-4 by mast cells. Ann. N. Y. Acad. Sci. 725, 50-58.

Ui, H., Andoh, T., Lee, J. B., Nojima, H., and Kuraishi, Y. (2006). Potent pruritogenic action of tryptase mediated by PAR-2 receptor and its involvement in anti-pruritic effect of nafamostat mesilate in mice. Eur. J. Pharmacol. 530, 172-178. doi: 10.1016/j.ejphar.2005.11.021
Urashima, R., and Mihara, M. (1998). Cutaneous nerves in atopic dermatitis. A histological, immunohistochemical and electron microscopic study. Virchows Arch. 432, 363-370. doi: 10.1007/s004280050179

van der Zee, H. H., de Ruiter, L., Boer, J., van den Broecke, D. G., den Hollander, J. C., Laman, J. D., et al. (2012). Alterations in leucocyte subsets and histomorphology in normal-appearing perilesional skin and early and chronic hidradenitis suppurativa lesions. Br. J. Dermatol. 166, 98-106. doi: 10.1111/j. 1365-2133.2011.10643.x

Walls, A. F., Brain, S. D., Desai, A., Jose, P. J., Hawkings, E., Church, M. K., et al. (1992). Human mast cell tryptase attenuates the vasodilator activity of calcitonin gene-related peptide. Biochem. Pharmacol. 43, 1243-1248. doi: 10. 1016/0006-2952(92)90498-8

Watanabe, N., Tomimori, Y., Terakawa, M., Ishiwata, K., Wada, A., Muto, T., et al. (2007). Oral administration of chymase inhibitor improves dermatitis in NC/Nga mice. J. Invest. Dermatol. 127, 971-973. doi: 10.1038/sj.jid.5700708

Weber, A., Knop, J., and Maurer, M. (2003). Pattern analysis of human cutaneous mast cell populations by total body surface mapping. Br. J. Dermatol. 148, 224-228. doi: 10.1046/j.1365-2133.2003.05090.x

Weidner, C., Klede, M., Rukwied, R., Lischetzki, G., Neisius, U., Skov, P. S., et al. (2000). Acute effects of substance P and calcitonin gene-related peptide in human skin-a microdialysis study. J. Invest. Dermatol. 115, 1015-1020. doi: 10.1046/j.1523-1747.2000.00142.x

Xiang, Z., and Nilsson, G. (2000). IgE receptor-mediated release of nerve growth factor by mast cells. Clin. Exp. Allergy 30, 1379-1386. doi: 10.1046/j.1365-2222. 2000.00906.x

Yamaguchi, J., Nakamura, F., Aihara, M., Yamashita, N., Usui, H., Hida, T., et al. (2008). Semaphorin3A alleviates skin lesions and scratching behavior in NC/Nga mice, an atopic dermatitis model. J. Invest. Dermatol. 128, 2842-2849. doi: 10.1038/jid.2008.150

Yamaoka, J., and Kawana, S. (2007). Rapid changes in substance P signaling and neutral endopeptidase induced by skin-scratching stimulation in mice. J. Dermatol. Sci. 48, 123-132. doi: 10.1016/j.jdermsci.2007.06.007

Yamaura, K., Oda, M., Suwa, E., Suzuki, M., Sato, H., and Ueno, K. (2009). Expression of histamine $\mathrm{H} 4$ receptor in human epidermal tissues and attenuation of experimental pruritus using $\mathrm{H} 4$ receptor antagonist. J. Toxicol. Sci. 34, 427-431. doi: 10.2131/jts.34.427

Yosipovitch, G., Mills, K. C., Nattkemper, L. A., Feneran, A., Tey, H. L., Lowenthal, B. M., et al. (2014). Association of pain and itch with depth of invasion and inflammatory cell constitution in skin cancer: results of a large clinicopathologic study. JAMA Dermatol. 150, 1160-1166. doi: 10.1001/jamadermatol.2014.895

Zhao, W., Oskeritzian, C. A., Pozez, A. L., and Schwartz, L. B. (2005). Cytokine production by skin-derived mast cells: endogenous proteases are responsible for degradation of cytokines. J. Immunol. 175, 2635-2642. doi: 10.4049/jimmunol. 175.4.2635

Zhu, Y., Pan, W. H., Wang, X. R., Liu, Y., Chen, M., Xu, X. G., et al. (2015). Tryptase and protease-activated receptor-2 stimulate scratching behavior in a murine model of ovalbumin-induced atopic-like dermatitis. Int. Immunopharmacol. 28, 507-512. doi: 10.1016/j.intimp.2015.04.047

Zhu, Y., Wang, X. R., Peng, C., Xu, J. G., Liu, Y. X., Wu, L., et al. (2009). Induction of leukotriene $\mathrm{B}(4)$ and prostaglandin $\mathrm{E}(2)$ release from keratinocytes by protease-activated receptor-2-activating peptide in ICR mice. Int. Immunopharmacol. 9, 1332-1336. doi: 10.1016/j.intimp.2009.08.006

Zuberbier, T., Aberer, W., Asero, R., Abdul Latiff, A. H., Baker, D., Ballmer-Weber, B., et al. (2018). The EAACI/GA(2)LEN/EDF/WAO guideline for the definition, classification, diagnosis and management of urticaria. Allergy 73, 1393-1414. doi: $10.1111 /$ all.13397

Conflict of Interest Statement: The authors declare that the research was conducted in the absence of any commercial or financial relationships that could be construed as a potential conflict of interest.

Copyright (c) 2019 Siiskonen and Harvima. This is an open-access article distributed under the terms of the Creative Commons Attribution License (CC BY). The use, distribution or reproduction in other forums is permitted, provided the original author(s) and the copyright owner(s) are credited and that the original publication in this journal is cited, in accordance with accepted academic practice. No use, distribution or reproduction is permitted which does not comply with these terms. 